

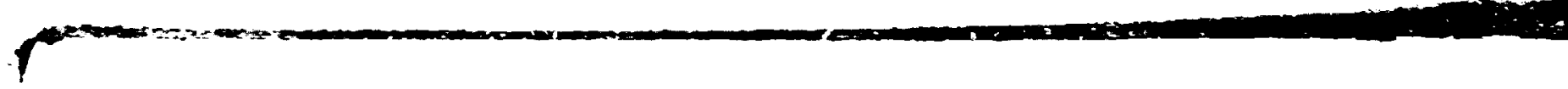

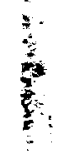

5
$\vdots$
$\vdots$ 


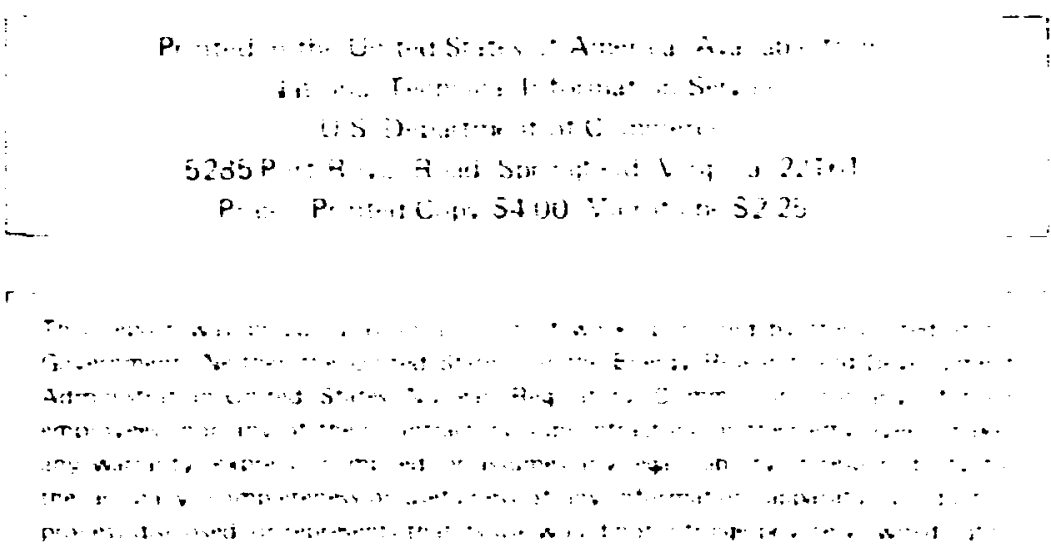


ond $/ \operatorname{csp} / 2 x-13$

Dist . Category Iic-12

Contract No. U-7405 eas 26

conptren sermaes division

INVESTIGATIOA OF THE SOLID AMEE METHOD APFIED

TO REFECTLD CUBIC ADAYS

J. S. Tans

Dote Published: Ocrober 1976

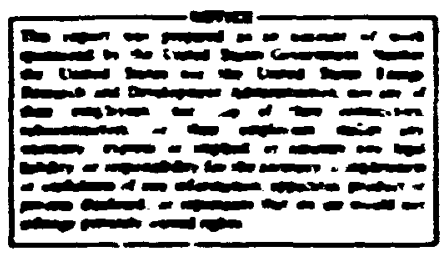

Work perforned for the U.S. Nuclear Regulatory Comisetion under Interagency Agreement 40-494-75.

MOTICE

This document contains informetion of a preliainary nature. Ic is subject to reviston or correction and therefore does not represent a final report.

IMION CARIDE CORPORATION, NUCLEAR DIVISION operating the

Oak RIdge Gaseous DIffusion Plant - Oak Ridge National Laboratory Oak RIdge Y-12 Plant - Paducah Gaseous Dif fuvion Plant for the ENERCY RESEARCH AND DEVELOPMANT ADMNISTRATON 


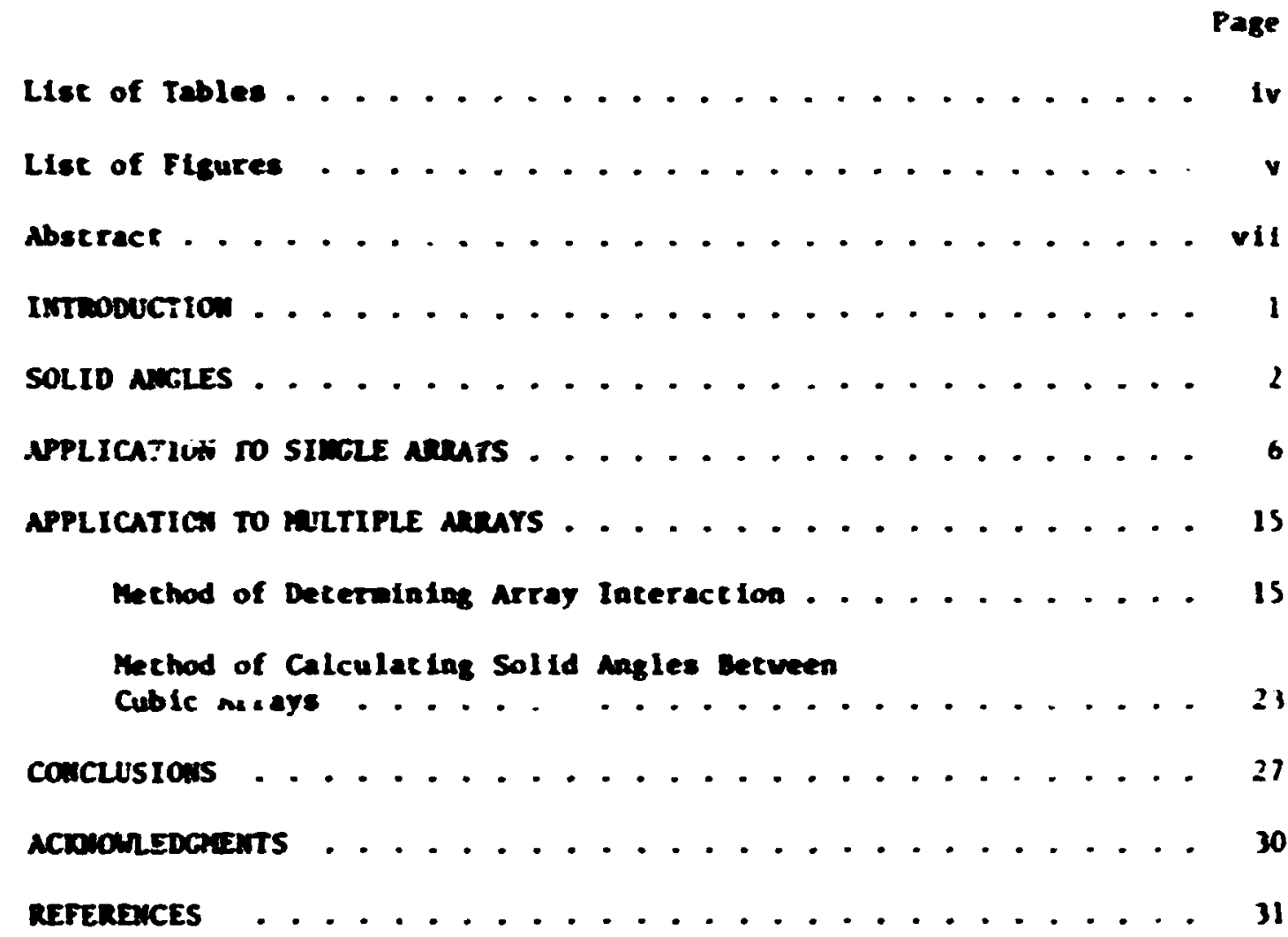




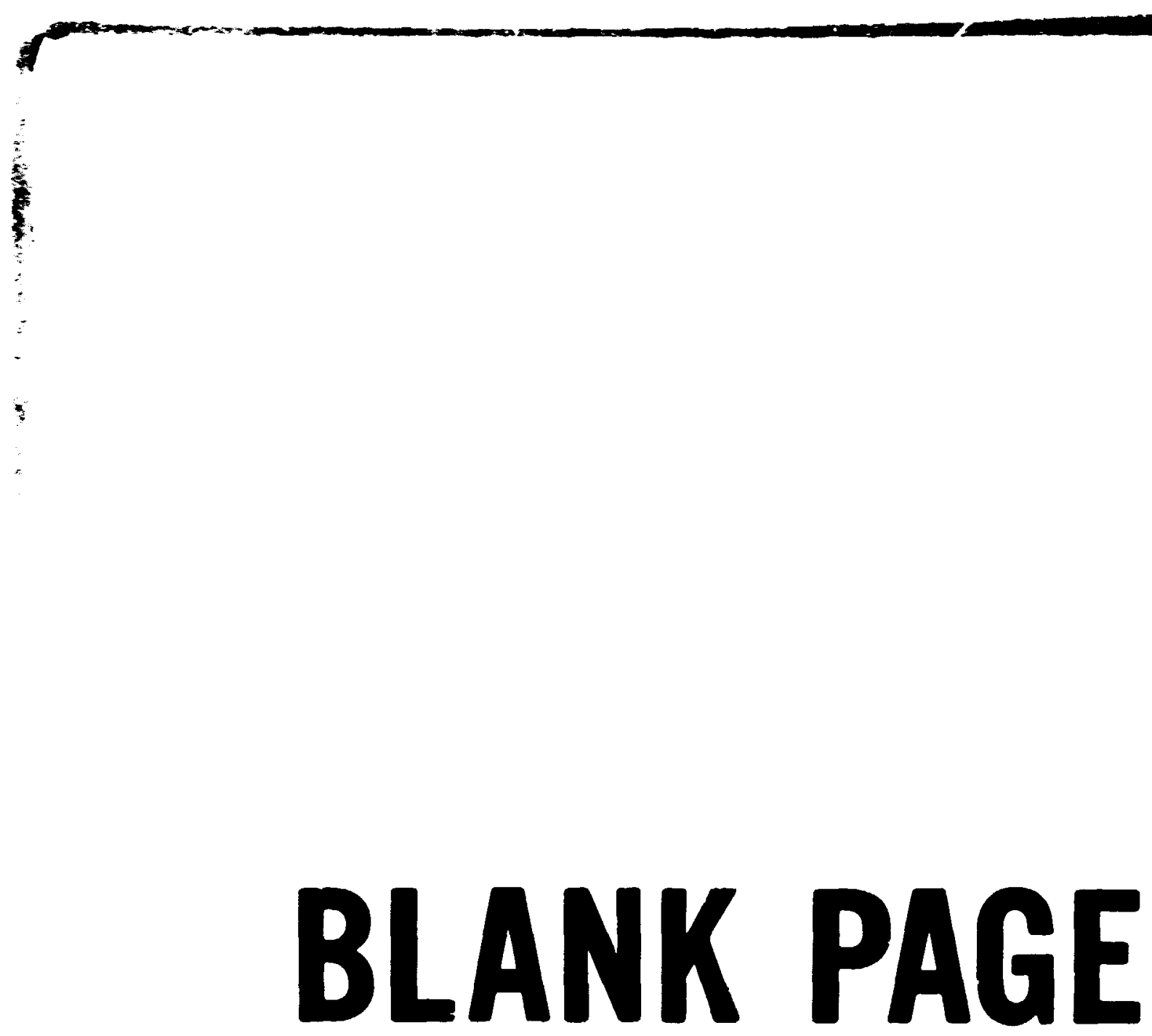




\section{LIST OF TARES}

\section{Table}

\section{Title}

$\Omega_{f}$ vs. K-eff of Single Unit for Arrays of $\mathrm{LO}_{2} \mathrm{~F}_{2}$

$\Omega_{f}$ vs. K-eff of Sirgle bit tor Arrays of $\mathrm{WO}_{2}\left(\mathrm{wO}_{3}\right)_{2}$

Unit I-eff and $\Omega_{f}$ Subtended on the Center Unit in 8 -Unit, Uater-Reflected, Critical cubic arrays of U(93.2) Hetal

Unit $k$-eff and $\Omega_{f}$ Subtended on the Center Unit in

v-Unit, Water-hef lected, Subcritical $(k-e f=.9)$

Cubic Arrays of U(93.?) Metal

Unit $K$-eff and $\Omega_{f}$ Subtended on the Cencer Unit in N-linit, Concrete-Ref lected, Critical Cubic Arrays of $\mathrm{U}(93.2)$ Metal

Unit R-eff and $\lambda_{f}$ Subtended on the Cencer Unit

in N-linit, Concrete-Reflected, Subcritical

$(k$-ef $f=.9)$ Cubic Arrays of $U(93.2)$ Hetal

$\Omega_{f}$ vs. K-eft of Individual Arrays for the NineArzay Systens

Array Dimension vs. Critical Separation for the Nive-Array Systens

$\Omega_{f}$ vs. K-eff of Irdividual array for System of 


\section{LIST OF FTGUES}

F1fure

1

2

3

4

5

6

7

8

9
Title

Average Solid Angle Becwean no Identical Spheres

Average Fractional Solid angle Detween To Parallel Slabs

Arerage Fractional Solid Angle Between No Identical Cylinders

$\partial_{f} v s$. $k$-eff of Individual Unit in Single-Array Systens

Top View of Nine-Cuibic Arrays Inside a S fuare Roon

$\Omega_{f}$ vs. K-eff oi sine-Cubic-Array Systea

$\Omega_{f} v 3$. th-eff of Individual Arrays in thultipleArray Systens

Top View of Ten-Cubic Arrays Inside a Square Roon

$\Omega_{f}$ vs. Array Separation in Hine-Cubic-Array Systens
Page

3

4

5

7

16

18

20

22

29 


\section{ASTRACT}

The solfd angle echod has been applied to neutron interactions between cublc asra:- of fissile aterials. Interaction curves for a nine-cublc-array systee is detenined. Interaction between units in singlearray systen is also inrestigated. It is found that the saf ty curve for unit inceraction given in IID-ij16 is not applicable to single ref lected cublc arrays of high enrichment fissile eaterials. 


\section{IMTroduction}

The solid angle nethod for representing neutron interactions between fissile units and evaluating criticality safety has been developed for nearly tweaty years. 1,2 Although there are other techniques for creating neitron interactions, the solid angle ethod, because of its sifflicisy In application, has been most videly used to determine safe spacing between fissile components.

This report revieus sume basic corcepts about solid angle and discusses erhods of calculating solid angles between a pair of ideatical units for the three basic geometries. Then, the solid angle enthed is applied to neutron interactior. In single-array systens which include reflected cubic arrays of spherical uraniun atal units and planar arrays of cy'indrical units of uranyl fluoride soiution and uranyl aitrate solution. Lastly, the application of the solid angle nethod is extended to neutron interaction in witiple array systems.

The ronce Carlo criticality progran, KEno ${ }^{3}$, is used for calculating the mltip'-ication factors, and the neutron cross sections are from the Hansen-Roach 16-gr' up daca set. 


\section{SOLID AKGLS}

The solid angle sutcended at a point by a surface is defined to be the projection of the surface on a sphere of unit radius surrounding the point. The fundanental unit of the solid angle is steradian. Thus the total solid angle subtended on a point is 4 steradians. In neutron interaction, the quantity of interest is the total fractional solid angle which is the cotal solid angle divided by $4 \pi$.

For an object utish is relatively simall compared to the distance away from a point, the solid angle subteaded on this point can be computed by the ratio of the area of the object tc the distance squared because this area is almost equal to its projected area on a sphere centered at the point. This simple relation provides a quick estimate of the solid angle, and it is applicable even when the area of the object is wot sali compred to the distance.

In studying neutron interaction between bodies of fissile materials, the average solid angle subtended on one body by the other is requirad. The average solid angles between a patr of cylinders, of spheres, and of slabs were computed ana!ytically, the first by Pond ${ }^{4}$ and the other two by Burton. 5,6 Approximate methods for calculating the average solid angles of chese geometries are also described in TID-7016." Figurt 1 provides a cosparison of the average solid angles between a pair of spheres calculated by the analytic and the approximate methods. Figures 2 and 3 provide the similar comparisons respectively for a pair of slabs and a pair of cylinders. It should be noted that the approximate method always overestimates the average solid angle. As far as nuclear criticality safety is concerned, this overestimation is conservative in determining safe spacings between fissile units. 


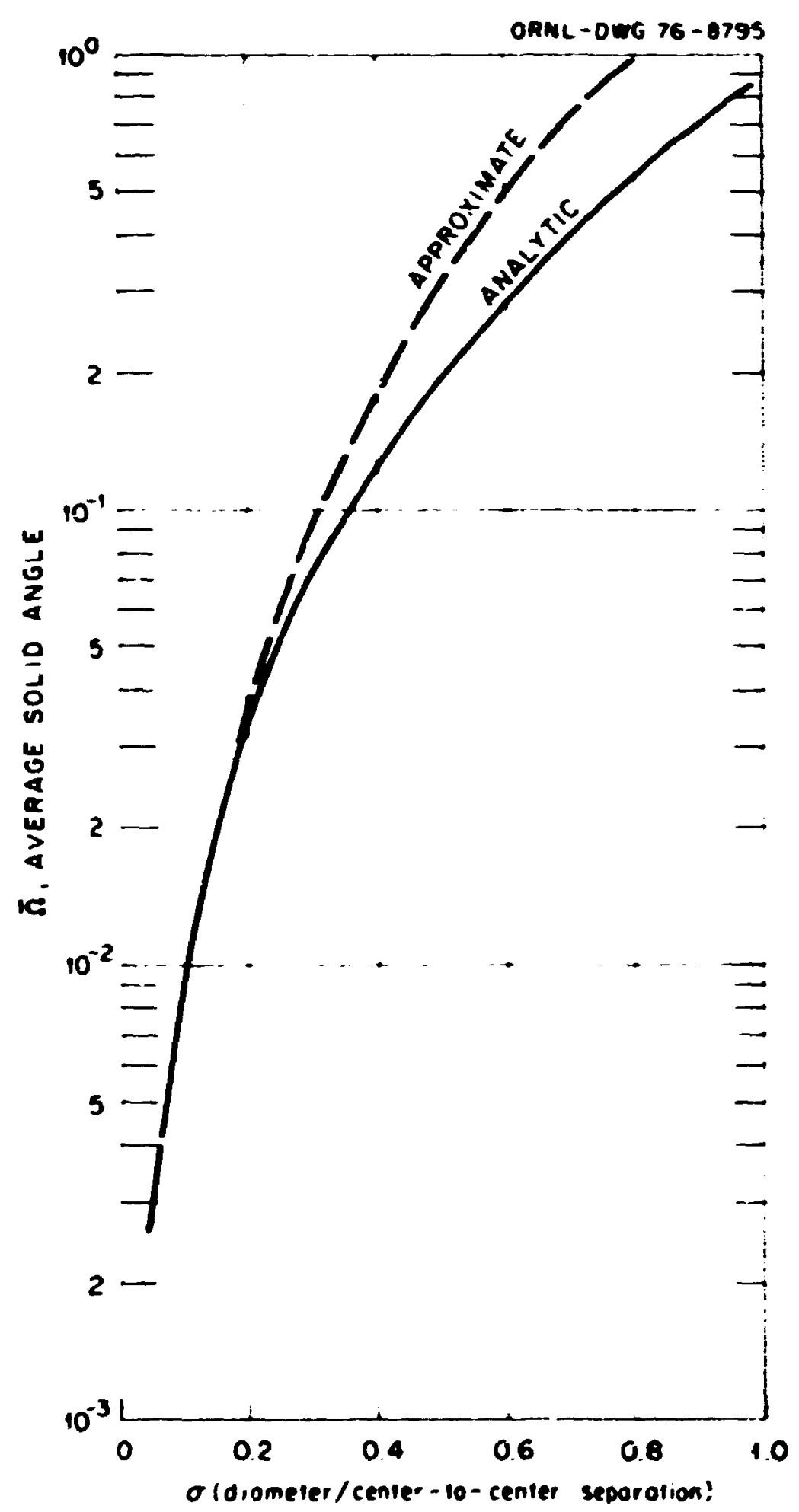

Figure 1. Average Solid Angle Between Two Identical Spheres 


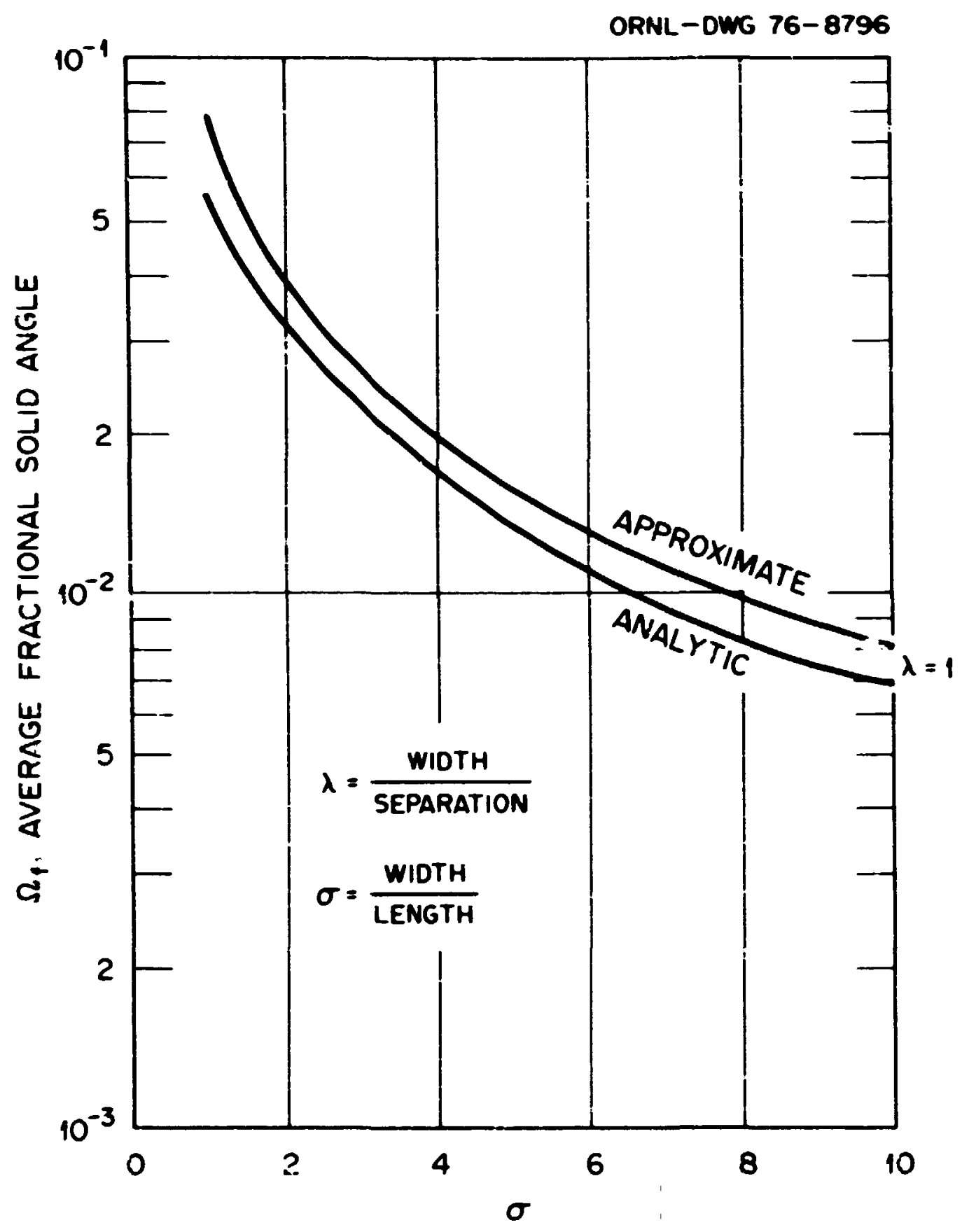

Figure 2. Average Fractional Solid Angle Between Two Parallel Slabs 


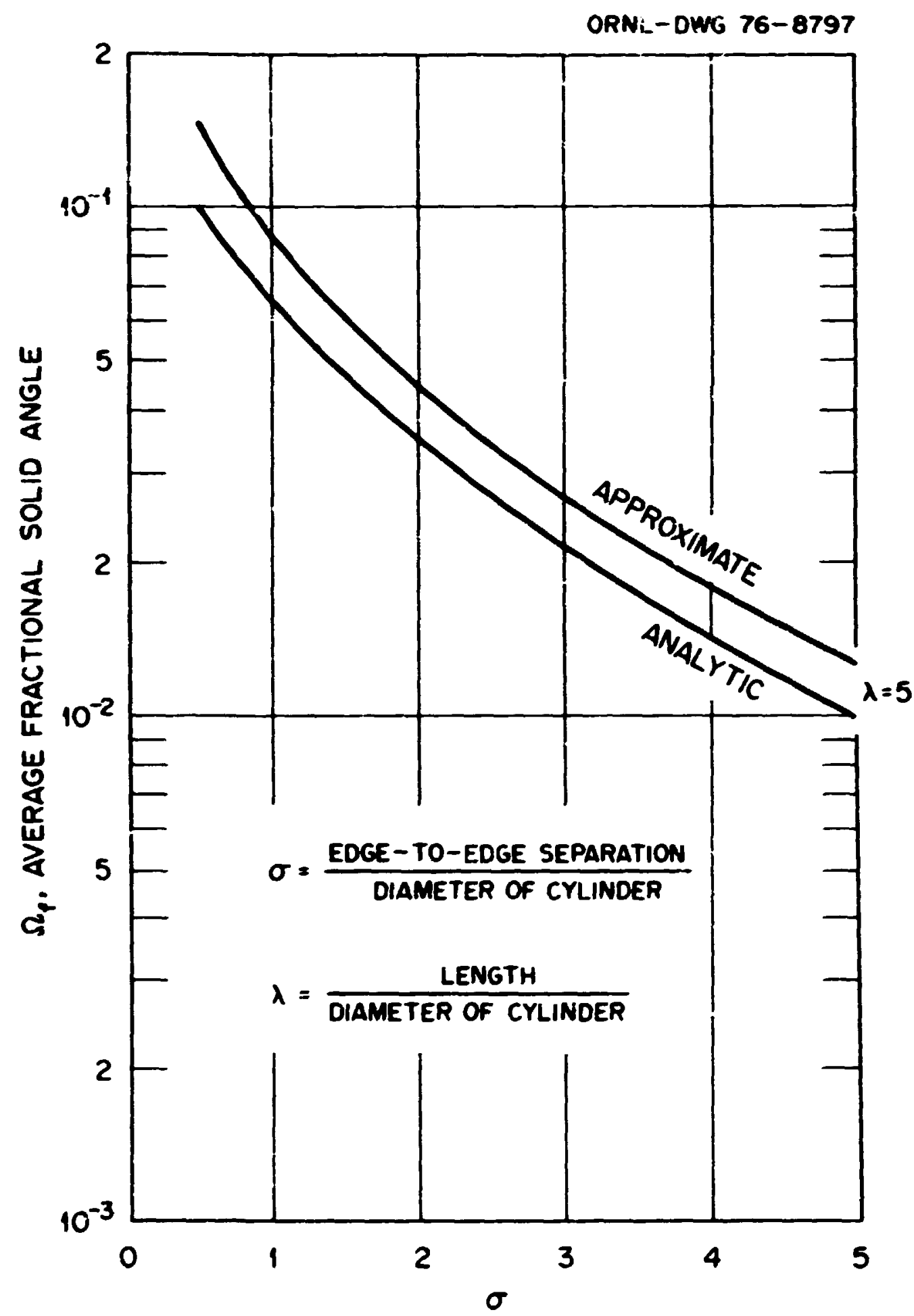

Figure 3. Average Fractional Solid Angle Between Two Identical Cylinders 


\section{APPLICATION TO SINGLE ARRAYS}

The solid angle method was originally developed for neutron interaction between fissile units in single arrays. 1,2 This method is based on the concept that neutron interactic - is inectly proportional to the solid angle subtended among fissile units and can be related to the neutron multiplication factor of an individial unit. Henry, et al., applled the solid angle method to study unit interaction of single planar arrays of highly enriched $v_{2} \mathrm{~F}_{2}$ solution. These arrays included cylindrical units and slab units in pairs and cylindrical units in triangular patterns. For each ar:ay, the total sverage solid angle was calculated by the analytic method, and the corresponding unit multiplication factor was determined by a two-group diffusion tineory.

In the present study, neutron interaction between units in single arrays was investigated for planar arrays of $\mathrm{VO}_{2} \mathrm{~F}_{2}$ and $\mathrm{UO}_{2}\left(\mathrm{NO}_{3}\right)_{2}$ solutions and for water-reflected and concrete-reflected cubic arrays of spherical uranium metal units. Critical experimental data for planar azrays of the uranyl solutions can be found in Refs. 1 and 8 , but paramete: 3 of the critical reflected cubic arrays can be calculated by the surface density method developed by Thomas. 9

Figure 4 contains results of unit interaction of the three fissile materials in terms of the cotal average fractional sold $\mathrm{J}$ angle $\Omega_{f}$ subtended on the center unit vs. the multiplication factor of an individual unit. The unit multipilcation factors for the uranyl solutions were calculated by the KENO code ${ }^{3}$ using Hansen-Roach 16-group neutron crosssection se:s. The multiplication factors of the uranium metal units were easily estimated ${ }^{9}$ from the undt radif and the critical radius of the uranium metal sphere. 


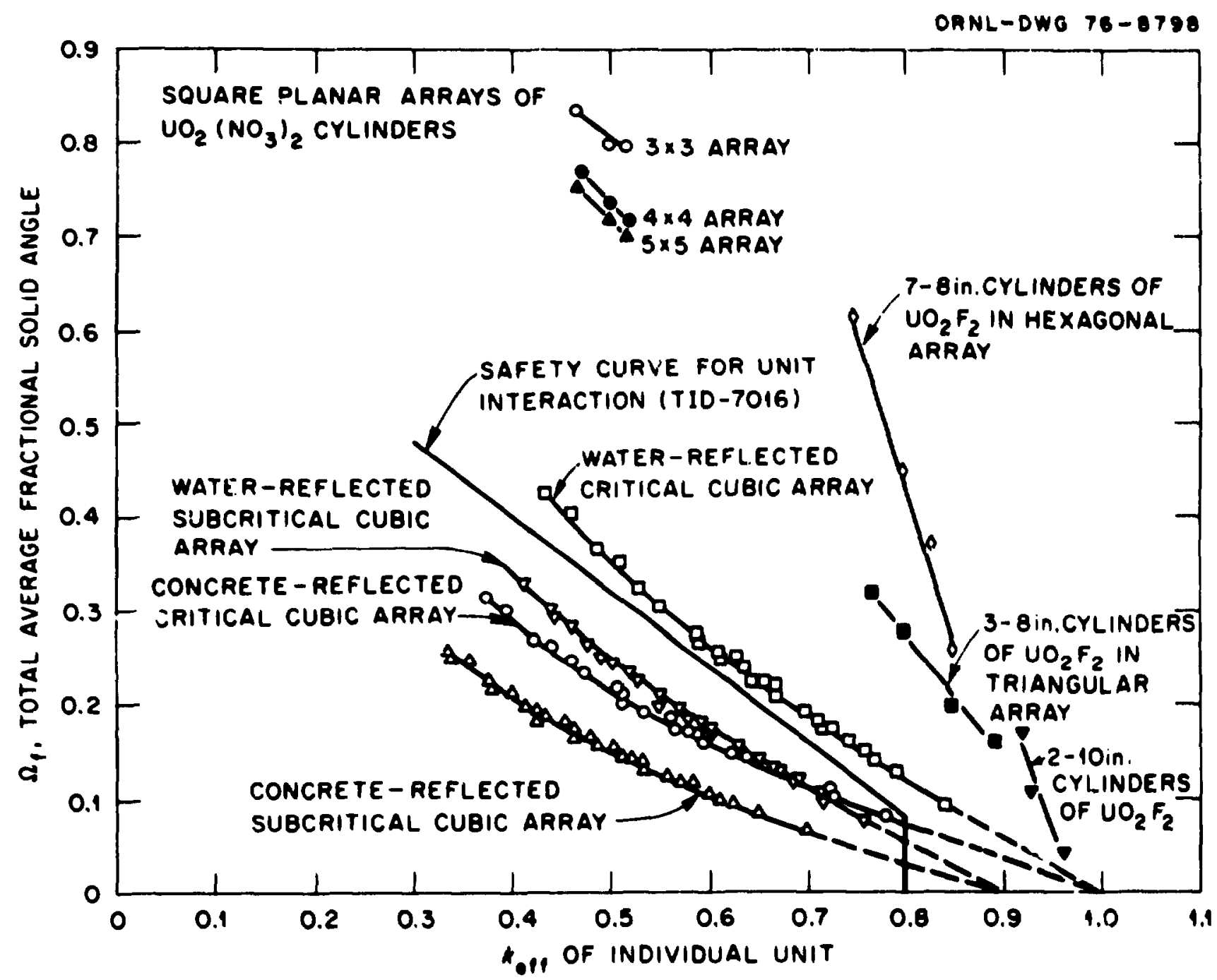

Figure 4. $\Omega_{f}$ vs. K-eff of Individual Unit in Single-Array Systems 
For the uranyl iluoride solution, three planar arrays of cylindrical units were examined, a pair and two arrays of triangular patterns. The results are presented in Table 1 and plotted in Fig. 4. The uranium enrichment of this solution is $v(93.4)$, and the specifications of the solution are presencos in Table 1 . The containers are ade of $0.41-\mathrm{cm}-$ thick aluminum. The aluminum container was not included in the unit $k$-eff calculations. However, the effect of the container was not significant. Three sases of unit ix-eff calculations with aluminum containers indicate that the increase in $k$-eff due to the presence of the container is no more than 1.7\%. The results of unit multiplication factors from Ref. 1 were also included in Table 1 for comparisun. It is observed that the two-group diffusion theory used in Ref. 1 overestimated the unit wult ipiication factors by $5 \%$ to $10 \%$.

Results of unit interaction of square planar arrays of uranyl nitrate soluticn are presented in Table 2 . The contalners were polyethylene cylinders with an average wall thickness of $0 . i 83 \mathrm{~cm}$. The polyethylene containers were included in calculating unit multiplication factors. It is interesting to note that. the average fractional solid angle is much larger for these arrays as compared to those of the uranyl fluoride solution.

Results of unit interacticn for reflected cubic arrays of $U(93.2)$ metal are presented in Tables $3,4,5$, and 6 . Tables 3 and 5 are respectively for critical water-reflected arrays and critical concrete-reflected arrays. Tables $:$ and 6 are for subcritical (k-eff $=0.9$ ) arrays. Data of these tables are graphically represented in Fig. 4. It is clear that the "safe-curve" for unit interaction recomended by TID-7016 cannot be used generally for reflected cubic arrays. 
Table 1. $\Omega_{f}$ vs. $K$-ef $f$ of Single Unit for Arrays of $\mathrm{UO}_{2} \mathrm{~F}_{2}$ Solution

\begin{tabular}{|c|c|c|c|}
\hline \multirow[b]{2}{*}{ Hefght (on) } & \multirow[b]{2}{*}{$\Omega_{\mathbf{f}}$} & \multicolumn{2}{|c|}{$\begin{array}{l}\text { K-eff of Single } \\
\text { Unit }\end{array}$} \\
\hline & & KENO & Ref. 1 \\
\hline \multicolumn{4}{|c|}{$\begin{array}{l}(H / U-235=169, \text { Specific Gravity=1.187, gm } U-235 / 8 m \\
\text { Solution }=.127)\end{array}$} \\
\hline $\begin{array}{l}28.7 \\
32.8 \\
37.2\end{array}$ & $\begin{array}{l}.166 \\
.104 \\
.040\end{array}$ & $\begin{array}{l}.916 \pm .006 \\
.930 \pm .002 \\
.961 \pm .006\end{array}$ & $\begin{array}{r}.9526 \\
.9824 \\
1.0077\end{array}$ \\
\hline
\end{tabular}

3 8" Dianeter Cylinders in Triangular Array (H/U-235=44.3, Specif ic Gravity $=1.66, g-U-235 / 8$ Solution=.32)

$\begin{array}{rlll}26.92 & .318 & .764 \pm .005 & .8444 \\ 35.05 & .272 & .798 \pm .006 & .8919 \\ 45.21 & .232 & .834 \pm .006 & .9237 \\ 55.88 & .20 & .846 \pm .006 & .9433 \\ 106.68 & .16 & .891 \pm .007- & .9732 \\ & & (.296 \pm .007) \star & \end{array}$

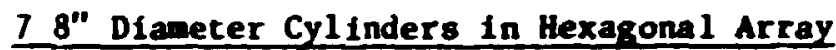
(H/U-235=44.3, Specif ic Gravicy=1.66, ge U-235/8m Solution=.32)

$\begin{array}{llll}25.65 & .612 & .747 \pm .006- & .8343 \\ & & (.760 \pm .007) \star & \\ 33.27 & .450 & .794 \pm .005 & .8836 \\ 41.66 & .372 & .829 \pm .005- & .9146 \\ & & (.830 \pm .005) \star & \\ 55.88 & .258 & .846 \pm .006 & .9425\end{array}$

*Aluminum container was included in these calculations. 
Table 2. $\Omega_{f}$ vs. K-eff of Single Unit for Arrays of $\mathrm{VO}_{2}\left(\mathrm{NO}_{3}\right)_{2}$ Solution*

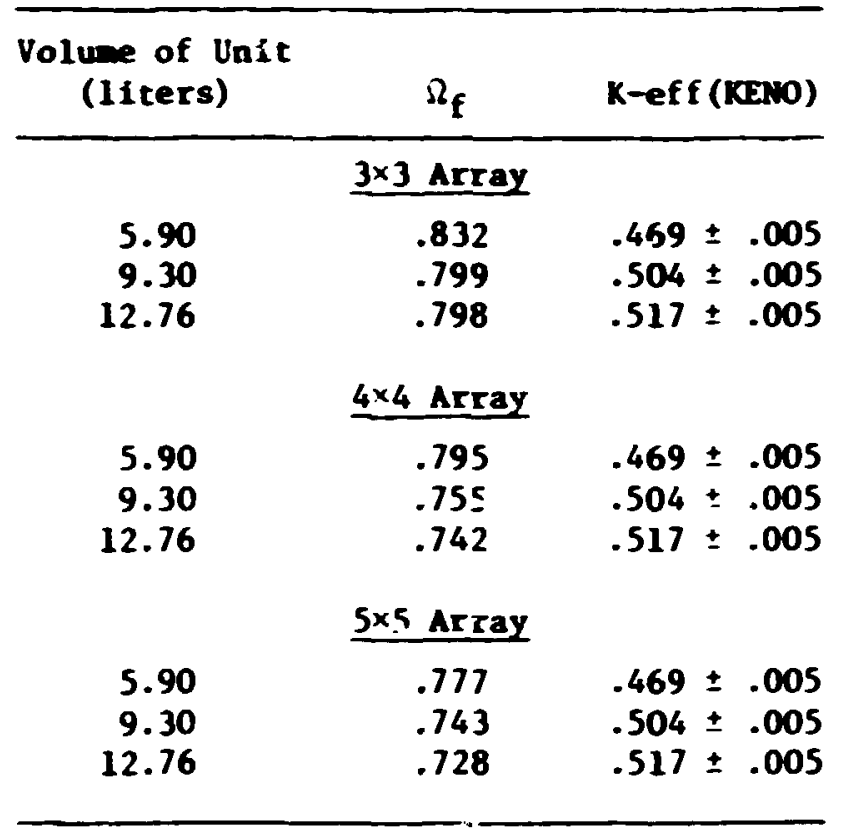

$\star_{H} / \mathrm{U}-235=59$, specific gravjty $=1.55$, $U-235$ concentration $=384 \mathrm{~g} / \mathrm{liter}$, and uranium enrichment $=92.6$ wtz of U-235. 
Table 3. Unit K-eff and $\Omega_{f}$ Su' tended on the Center Unit in N-Unit, Water-Refle.ted, Critical Cubic Arrays of U(93.2) Metal

\begin{tabular}{|c|c|c|c|c|c|c|}
\hline \multirow[b]{2}{*}{$\mathbf{N}$} & \multicolumn{6}{|c|}{ Half-Cell Dimension (ca) } \\
\hline & 12.70 & 15.24 & 19.05 & 22.86 & 25.40 & 30.48 \\
\hline 125 & $\begin{array}{l}.586 \star \\
.266\end{array}$ & $\begin{array}{l}.643 \\
.222\end{array}$ & $\begin{array}{l}.712 \\
.174\end{array}$ & $\begin{array}{l}.766 \\
.140\end{array}$ & $\begin{array}{l}.794 \\
.122\end{array}$ & $\begin{array}{l}.839 \\
.095\end{array}$ \\
\hline 343 & $\begin{array}{l}.528 \\
.328\end{array}$ & $\begin{array}{l}.584 \\
.278\end{array}$ & $\begin{array}{l}.654 \\
.223\end{array}$ & $\begin{array}{l}.710 \\
.183\end{array}$ & $\begin{array}{l}.742 \\
.162\end{array}$ & $\begin{array}{l}.793 \\
.128\end{array}$ \\
\hline 729 & $\begin{array}{l}.488 \\
.361\end{array}$ & $\begin{array}{l}.542 \\
.309\end{array}$ & $\begin{array}{l}.611 \\
.251\end{array}$ & $\begin{array}{l}.669 \\
.209\end{array}$ & $\begin{array}{l}.701 \\
.186\end{array}$ & $\begin{array}{l}.756 \\
.150\end{array}$ \\
\hline 1331 & $\begin{array}{l}.458 \\
.409\end{array}$ & $\begin{array}{l}.510 \\
.352\end{array}$ & $\begin{array}{l}.578 \\
.289\end{array}$ & $\begin{array}{l}.635 \\
.243\end{array}$ & $\begin{array}{l}.668 \\
.2: 8\end{array}$ & $\begin{array}{l}.724 \\
.177\end{array}$ \\
\hline 2197 & $\begin{array}{l}.435 \\
.425\end{array}$ & $\begin{array}{l}.485 \\
.368\end{array}$ & $\begin{array}{l}.551 \\
.304\end{array}$ & $\begin{array}{l}.608 \\
.257\end{array}$ & $\begin{array}{l}.641 \\
.231\end{array}$ & $\begin{array}{l}.698 \\
.190\end{array}$ \\
\hline
\end{tabular}

*For each $N$, the first row is the unit $k$-eff and the second row is the $\Omega_{f}$. 
Table 4. Unit $K$-ef $f$ and $\Omega_{f}$ Subtended on the Center Unit

in $N$-lnit, Water-Ref lected, Subcritical ( $k$-ef $f=.9)$

Cubic Arrays of U(93.2) Metal

\begin{tabular}{lllllll}
\hline & \multicolumn{6}{c}{ Half-Cell Dimension (cm) } \\
\cline { 2 - 7 }$N$ & 12.70 & 15.24 & 19.05 & 22.86 & 25.40 & 30.48 \\
\hline 125 & $.527 \star$ & .579 & .041 & .689 & .715 & .756 \\
& .215 & $.18 C$ & .141 & .113 & .099 & .076 \\
343 & .475 & .525 & .589 & .639 & .668 & .714 \\
& .265 & .225 & .181 & .148 & .131 & .104 \\
729 & .439 & .488 & .550 & .602 & .631 & .680 \\
& .292 & .250 & .204 & .169 & .151 & .121 \\
1331 & .412 & .459 & .520 & .572 & .602 & .652 \\
& .331 & .285 & .234 & .197 & .176 & .144 \\
2197 & .391 & .437 & .496 & .547 & .577 & .628 \\
& .344 & .298 & .246 & .208 & .187 & .154 \\
& & & & & & \\
\hline
\end{tabular}

*For each $N$, the first iow is the unit $k$-eff and the second row is the $\Omega_{f}$. 
Table 5. Unit $K$-eff and $\Omega_{f}$ Subtended on the Center Unit in N-Unit, Concrete-Reflected, Critical Cubic Arrays of U(93.2) Hetal

\begin{tabular}{lllllll}
\hline & \multicolumn{6}{c}{ Half-Cell } \\
\cline { 2 - 7 }$N$ & 12.70 & 15.24 & 19.05 & 22.86 & 25.40 & 30.48 \\
\hline 125 & $.512 \star$ & .567 & .637 & .694 & .726 & .778 \\
& .203 & .173 & .139 & .115 & .102 & .081 \\
343 & .458 & .510 & .578 & .635 & .668 & .724 \\
& .246 & .212 & .174 & .146 & .131 & .107 \\
729 & .422 & .471 & .536 & .592 & .626 & .683 \\
& .269 & .233 & .193 & .164 & .148 & .122 \\
1331 & .395 & .442 & .505 & .560 & .592 & .650 \\
& .304 & .264 & .220 & .188 & .171 & .143 \\
$219 ?$ & .374 & .419 & .480 & .533 & .565 & .622 \\
& .314 & .274 & .230 & .197 & .179 & .151 \\
& & & & & & \\
\hline
\end{tabular}

«For each $\mathrm{N}$, the first row is the unit $k$-eff and the second row is the $\Omega_{f}$. 
Table 6. Unit $k$-eff and $\Omega_{f}$ Subtended on the Center Unit

in $N$-Unit, Concrete-Ref lected, Subcritical $(k-\cdots f=.9)$

Cubic Arrays of U(93.2) Metai

\begin{tabular}{|c|c|c|c|c|c|c|}
\hline \multirow[b]{2}{*}{$\boldsymbol{N}$} & \multicolumn{6}{|c|}{ Half-Cell Dimension (ca) } \\
\hline & 12.70 & 15.24 & 19.05 & 22.86 & 25.40 & 30.49 \\
\hline 125 & $\begin{array}{l}.461 \star \\
.164\end{array}$ & $\begin{array}{l}.510 \\
.140\end{array}$ & $\begin{array}{l}.573 \\
.113\end{array}$ & $\begin{array}{l}.625 \\
.093\end{array}$ & $\begin{array}{l}.653 \\
.082\end{array}$ & $\begin{array}{l}.700 \\
.066\end{array}$ \\
\hline 343 & $\begin{array}{l}.412 \\
.199\end{array}$ & $\begin{array}{l}.459 \\
.172\end{array}$ & $\begin{array}{l}.520 \\
.141\end{array}$ & $\begin{array}{l}.571 \\
.118\end{array}$ & $\begin{array}{l}.601 \\
.106\end{array}$ & $\begin{array}{l}.652 \\
.086\end{array}$ \\
\hline 729 & $\begin{array}{l}.379 \\
.218\end{array}$ & $\begin{array}{l}.424 \\
.189\end{array}$ & $\begin{array}{l}.483 \\
.157\end{array}$ & $\begin{array}{l}.533 \\
.133\end{array}$ & $\begin{array}{l}.563 \\
.120\end{array}$ & $\begin{array}{l}.614 \\
.099\end{array}$ \\
\hline 1331 & $\begin{array}{l}.355 \\
.246\end{array}$ & $\begin{array}{l}.398 \\
.214\end{array}$ & $\begin{array}{l}.454 \\
.179\end{array}$ & $\begin{array}{l}.504 \\
.152\end{array}$ & $\begin{array}{l}.533 \\
.138\end{array}$ & $\begin{array}{l}.585 \\
.115\end{array}$ \\
\hline 2197 & $\begin{array}{l}.336 \\
.255\end{array}$ & $\begin{array}{l}.377 \\
.222\end{array}$ & $\begin{array}{l}.432 \\
.186\end{array}$ & $\begin{array}{l}.480 \\
.160\end{array}$ & $\begin{array}{l}.509 \\
.145\end{array}$ & $\begin{array}{l}.560 \\
.122\end{array}$ \\
\hline
\end{tabular}

\#For each $N$, the first row is the unit $k$-eff and the second row is the $\Omega_{\mathrm{f}}$. 
It should be noted that the average solid angles between units were calculated by the exact analytic mothod and not by the approximate formulae given in TID-7016. Moreover, in salculating the solid angles between units in an array, partially shadowed units are treated as though no shadowing were presenc and fully shadowed units are ignored.

\section{APPLICATION TO MULTIPLE ARRAYS}

Application of the solid angle method to neutron interaction between multiple arrays of fissile materials was undertaken in this work. The Monte Carlo criticality code, KENo ${ }^{3}$, with Hansen-Roach 16-group neutron cross-section data set was used for k-eff calculation.

\section{Method of Determining Array Interaction}

Cubic arrays of 216 air-spaced units of $U(93.2)$ metal spheres centered in cubic ceils were chosen for this study. Three cubic arrays were considered, each conposed of $10 \mathrm{~kg}$ unfts, $15 \mathrm{~kg}$ untts, and $20 \mathrm{~kg}$ units. The parameters of each array were chosen so that the array would be critical if it were fully reflected by water, since water is a reference reflector material against which reflector effects are evaluated in safety analyses.

Nine Identical arrays were arranged in a square pattern at the center of a room as shown in Fig. 5. The dimensions of the room were 18.3 by $18.3 \mathrm{~m}$ square and $4.6 \mathrm{~m}$ high $(60 \times 60 \times 15 \mathrm{ft}$.$) . The room's walls, floor,$ and celling were assume.l to be concrete $0.4 \mathrm{~m}$ thick $(16-1 \mathrm{n}$.$) . The neu-$ tron multiplication factor of this system was calculated by KeNo. The total average fractional solid angle $\Omega_{f}$ suhtended on the center array was determined by an approximate method which is described in the next section. 
OANK-OWG 76-8793

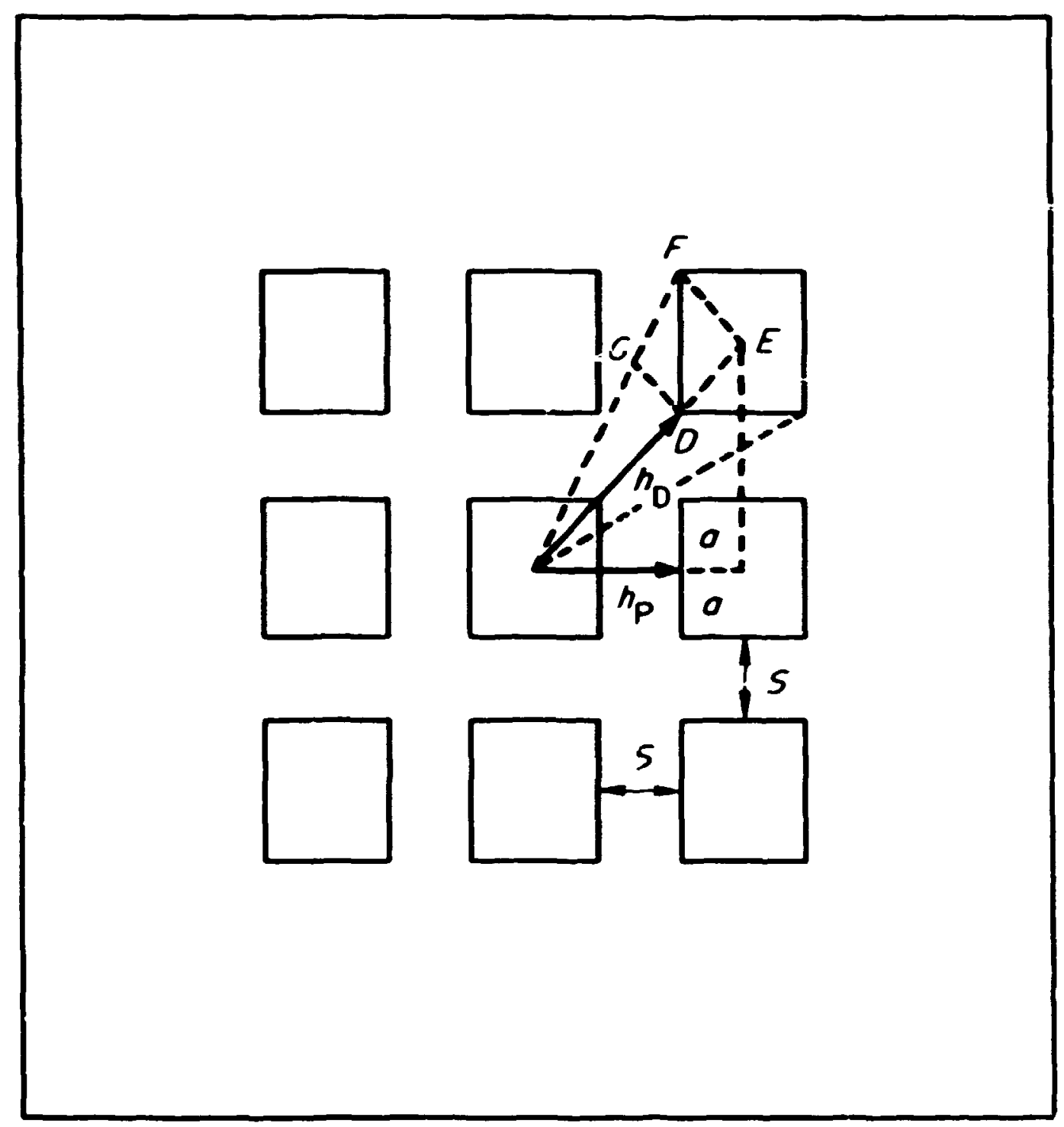

Figure 5. Top View of Nine-Cubic Arrays Inside a Square Room 
Four sets of $k$-eff and $i_{f}$ corresponding to four different array separations were calculaced for each of the three selected arrays. Results of these calculations were plotted in Fig. 6. The $\Omega_{f}$ at k-ff $=1.0$ for che systel of arrays in this figure represents a easure of neutron inceraction between alciple arrays when the gysten is critical. Thus, th: critical $\Omega_{f}$ for each critical ulcjple array systen can be directly determined tron Fig. 6.

Depending on its location in the roon, an individual array wil have different values of $k$-eff due to the different contributions of neutron reflection from the concrete enclosing the roon. It is clear that the array $k$-eff is maxima when the array is at a corner of the room and ainime when the array is at the center of the r:on. The axian and ainim array mitiflication factors were calculated by KEvo and are listed in Table 7 along with their corrosponding $\Omega_{f}$ 's for the three wultiple-array systems. The results of this table are displayed in Fig. 7 .

In criticality safety analyses, the interaction curve for subcritical systems at $k$-eff $=0.9$ is quite useful because it can be used as a safety curve for interaction. The interaction curve at $k$-eff $=0.9$ for the nine-array systems can be obcained by asumbing thet the reactivity change of the system is directly proportional to the reactivity change of the array. This concept is an extension of the dewonstrated result for units In an arra;, 1.e., array reactivity changes are directly proportional to uniform changes in the reactivity of che units. 9 Thus,

$$
\frac{\Delta k}{k \text { system }}=\frac{\Delta k}{k} \text { array }
$$

In order to check the validity of this equation, a kExo calculation was 


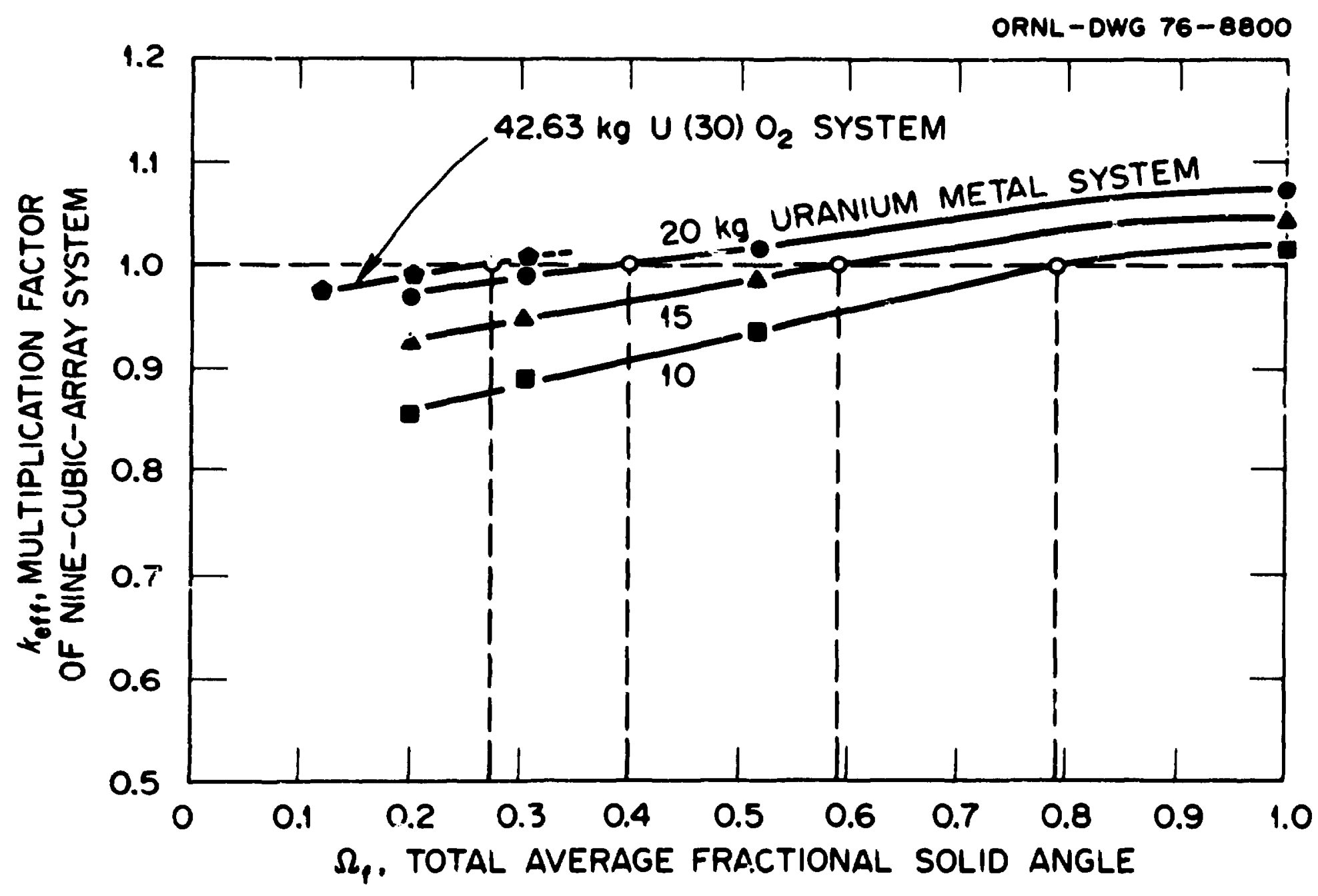

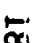

Figure 6. $\Omega_{f}$ vs. K-ef $f$ of Nine-Cubic-Array System 
Table 7. $\Omega_{f}$ vs. K-eff of Individual Arrays for the Nine-Array Systens

\begin{tabular}{|c|c|c|c|}
\hline \multirow[b]{2}{*}{ Array Type } & \multirow[b]{2}{*}{$\Omega_{\mathrm{f}}$} & \multicolumn{2}{|c|}{$\begin{array}{c}\text { K-eff of Individual } \\
\text { Array }\end{array}$} \\
\hline & & $\operatorname{Max}$ & Min \\
\hline $10 \mathrm{~kg}$ eecal & .78 & .89 & .77 \\
\hline $15 \mathrm{~kg}$ vetal & .58 & .91 & .83 \\
\hline $20 \mathrm{~kg}$ metal & .40 & .92 & .85 \\
\hline $\begin{array}{c}42.63 \mathrm{~kg} \mathrm{U}(30) \mathrm{O}_{2} \\
(\mathrm{H} / U=.4)\end{array}$ & .28 & .92 & \\
\hline
\end{tabular}




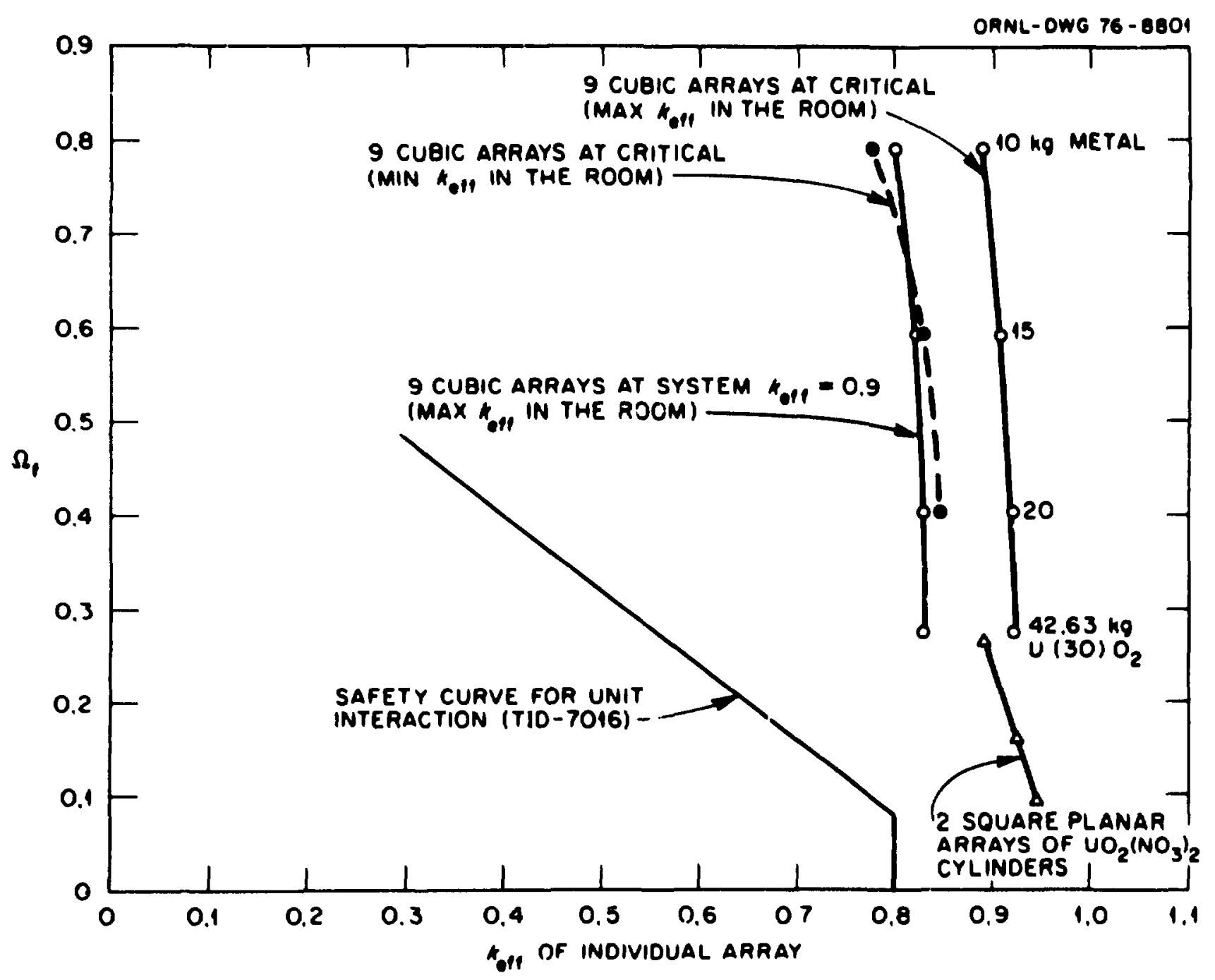

Figure 7. $\Omega_{\mathrm{f}}$ vs. K-ef $\mathrm{f}$ of Individual Arrays in Multiple-Array Systems 
performed for a nine-array systea which has a critical $\Omega_{f}$ and an array mitiplication factor of 0.9 . The result gave a systen auliplication factor of $0.8922 \pm .0053$. With this simple relation, the interaction curves at $k$-eff $=0.9$ for the nine-arras systen were obtained.

The shadowing effect is a shortconing of the solid angle nethod because it complicates solid angle calculations and introduces uncertainties in representing neutron interactions. For exanple, the solid angle method does not account for neutron interaction between completely shadowed components. This was demonstrated for the nine-array, $20 \mathrm{~kg}$ uraniun eetal systen. A tenth array was added to the nine-array systen which has a calculated multiplication factor of $.9989 \pm .0050$. The tenth array was located on the second row so that it was completely shadowed from the center array as shown in Fig. 8. Although the total average fractional solid angles subtended on the center array for both systeas are equal because of shadowing, the ten-array system should have a higher reactivity than the nine-array systen. Indeed, for the cen-array system a multiplication factor of $1.0206 \pm .0049$ was obtained by a KENO calculation. Compared to that of the nine-array system, this witiplication factor is higher by $2 \pi$.

Although the interaction curves in Fig. ? were obtained for U(93.2) metal, they are applicable to $46 \mathrm{different}$ fissile material compositions of which the characteristic constants $C_{2}$ and the spherical bare critical mass $M_{n}$ are known. 10 Due to the generic nacure of reflected arrays, 9 the uranium metal units in the cubic arrays may be replaced by equivalent units of other fissile materials without changing the array multiplication factor and thus the system multiplication factor. This was 


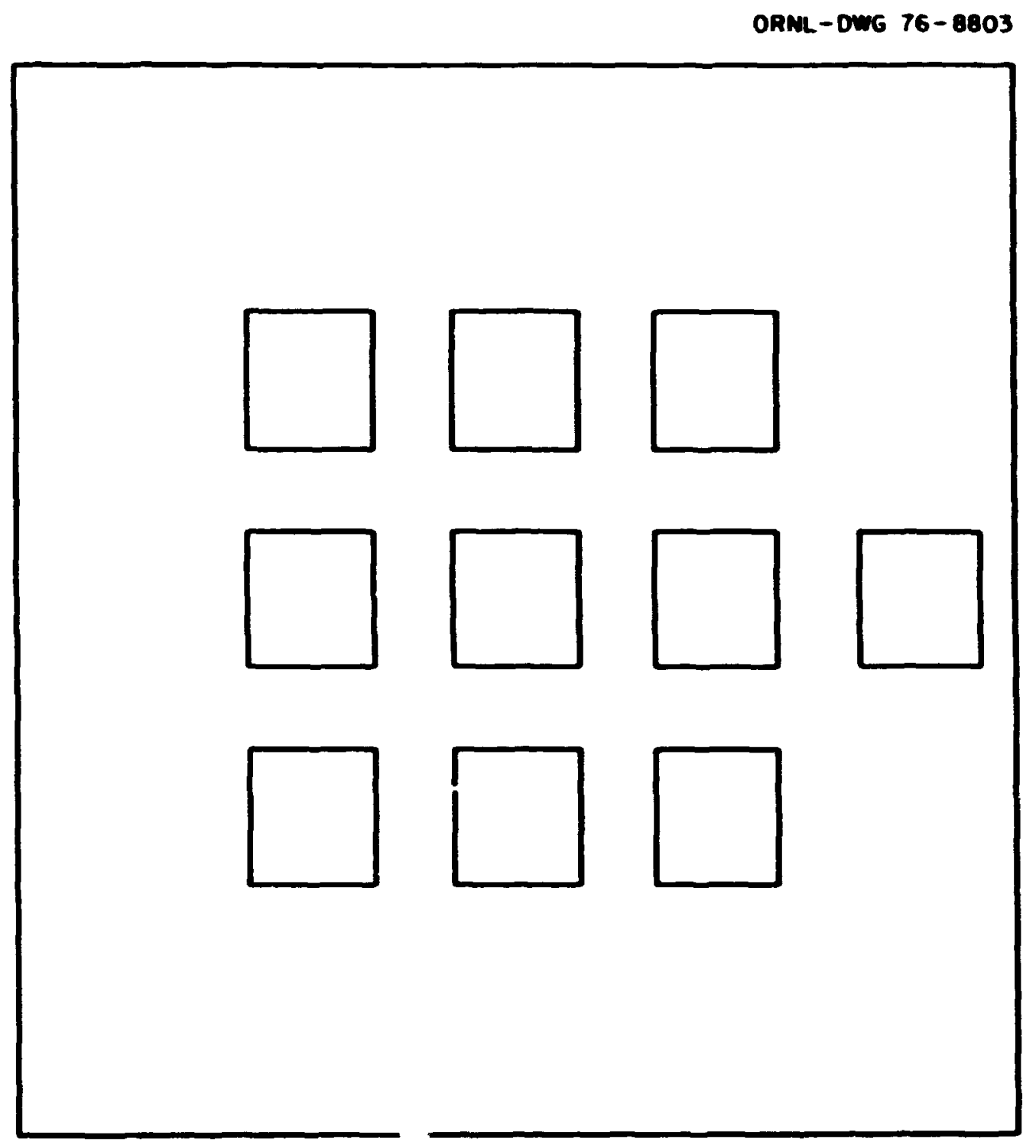

Figure 8. Top View of Ten-Cublc Arrays Inside a Square Room 
deronstrated for the uraniwe oxide anterlal $\left(\mathrm{L}(30) \mathrm{O}_{2}, \mathrm{H} / \mathrm{L}=.4\right)$. A ninearray uraniue oxide systee was coastructad by replacing the 20 ks actal uaits in the nime-array 20 kg uraniu metal system by equivalent 9 oxide spherical units. The altiplication factor of the oxide systee we calculated to be $0.9966 \cdot .0064$ while the eultiplication factor of the $20 \mathrm{~kg}$ ental system wa .998, .0050. For all practical purposes. the two-systea mitiplication factors are equal.

The study on erray interaction was carried out further to include cublc arrays of 512 epherical units of the uraniw oxide mterial. Because of the larger array size, the roos was exparded to 75 feet square. The critical if and the maximan $k$-eff of an individual array were deteralned and Included in Table 7 and plocted in Fig. 7.

Finally. for the cublc array systeas the cricical separation versus the array dimension is presented in Table 8 . Soce that the critical separation is sall for anall arrays and becomes larger for larger arrays. Moreover, the critical ceparation is always less than the array dimension for all four systems.

Interaction between two square planar arrays of $\mathrm{LO}_{2}\left(\mathrm{NO}_{3}\right)_{2}$ cy:inders was also calculated since the critical experiments daca were avallable In the oral-3193 report. 8 The solid angle hetween the two square planar arrays was computed by the center-to-edge formula. The results of if versus $k$-eff of individual arrays are presented in Table 9 and displayed in Fig. 7.

Method of Calculating Solid Angles Between Cublc Arrays

For the cublc arrays arranged in square patterns as show in Fig. 5 , the solid angle subtended on the central array is calculated by a rather 
Table 8. Array Dimension vs. Critical Separation for the Nine-Array Systens

\begin{tabular}{ccc}
\hline Array Type & $\begin{array}{c}\text { Array Dimension } \\
\text { (c.a) }\end{array}$ & $\begin{array}{c}\text { Separation } \\
\text { (ca) }\end{array}$ \\
\hline $10 \mathrm{~kg}$ metal & 164 & 18 \\
$15 \mathrm{~kg}$ metal & 214 & 55 \\
$20 \mathrm{~kg}$ metal & 266 & 133 \\
$32.63 \mathrm{~kg} U(30) \mathrm{O}_{2}$ & 354 & 236 \\
$(\mathrm{H} / \mathrm{U}=.4)$ & & \\
\hline
\end{tabular}


Table 9. $\Omega_{f}$ vs. K-eff of Individual Array for Systen of Two Square Arrays of $\mathrm{WO}_{2}\left(\mathrm{NO}_{3}\right)_{2}$

(12.76 $\ell /$ unit)

\begin{tabular}{ccc}
\hline Array Type & $\Omega_{f}$ & $\begin{array}{c}\text { K-eff of Individual } \\
\text { Array }\end{array}$ \\
\hline $4 \times 4$ & .096 & $.945 \pm .005$ \\
$5 \times 5$ & .159 & $.926 \pm .006$ \\
$7 \times 7$ & .268 & $.887 \pm .006$ \\
\hline
\end{tabular}


simple eethod. Given the array dimension 2a and the array separation s, the solid angle subtended on the central array by a nearby parallel array is approxianted by the center-to-edge formula as: 4

$$
\Omega_{p}=4 \sin ^{-1} \frac{a^{2}}{h_{p}^{2}+a^{2}}
$$

where $h_{p}=s+a$. By using the center-to-edge approximution, the solid angle subtended on the central array by a diagonal array is defined to be:

$$
\Omega_{D}=4 \sin ^{-1} \frac{a b}{\left(\sqrt{h_{D}^{2}+a^{2}}\right)\left(\sqrt{h_{D}^{2}+b^{2}}\right)}
$$

where $h_{D}$ is the distance from che center of the central array to the nearest corner of the diagonal array and $i s$ equal to $h_{p} \sqrt{2}$, and $b$ is determined below. It can be seen frea Fig. 5 that

$$
\frac{D G}{E F}=\frac{C D}{C E}
$$

or

$$
\frac{b}{a \sqrt{2}}=\frac{h_{D}}{(s+2 a) \sqrt{2}}
$$

Thus

$$
b=h_{D} \frac{a}{s+2 a} .
$$

The total average fractional solid angle subtended on the contral array by the eight surrounding arrays is

$$
\partial_{f}=\frac{1}{4 \pi}\left(4 \Omega_{p}+4 \Omega_{D}\right) .
$$


Listed in Table 10 are values of $\Omega_{p}, \Omega_{p}$, and $\hat{\sigma}_{f}$ corresponding to eight different array separations expressed in terms of a. Figure 9 is a plot of $\lambda_{f}$ vs. array separation.

roxclusions

For single array systems, the safe interaction curve given in TID-7016 is applicable to pianar arrays but not necessarily to reflected cubic arrays. The interaction cirves for the water-ref lected and concreteref lected single cubic arrays at array miciplication factors of 0.9 may be used as the safety curves for interaction for these two kinds of ref lected cubic srrays.

For mitiple array systeas, the interaction curves fo: nine cublc arrays and for two square planar arrays have been deternined. From these interaction curves, a safety curve for array interactions could be established. 
Table 10. Solid Angle vs. Array Separation

\begin{tabular}{|c|c|c|c|}
\hline $\begin{array}{l}\text { Array Separation } \\
\text { (in terns of a) }\end{array}$ & $\Omega_{p}$ (steradian) & $R_{0}$ (steradian) & $\Omega_{\mathbf{f}}$ \\
\hline $\begin{array}{l}0 \\
a / 3 \\
2 / 3 a \\
a \\
4 / 3 a \\
5 / 3 a \\
2 a \\
7 / 3 a \\
8 / 3 a \\
3 a \\
10 / 3 a \\
11 / 3 a \\
4 a\end{array}$ & $\begin{array}{l}2.09 \\
1.47 \\
1.07 \\
.81 \\
.62 \\
.49 \\
.40 \\
.33 \\
.28 \\
.24 \\
.21 \\
.18 \\
.15\end{array}$ & $\begin{array}{l}1.05 \\
.74 \\
.55 \\
.42 \\
.33 \\
.27 \\
.22 \\
.19 \\
.16 \\
.14 \\
.12 \\
.10 \\
.09\end{array}$ & $\begin{array}{l}.999 \\
.705 \\
.516 \\
.391 \\
.305 \\
.263 \\
.198 \\
.165 \\
.139 \\
.118 \\
.105 \\
.089 \\
.078\end{array}$ \\
\hline
\end{tabular}




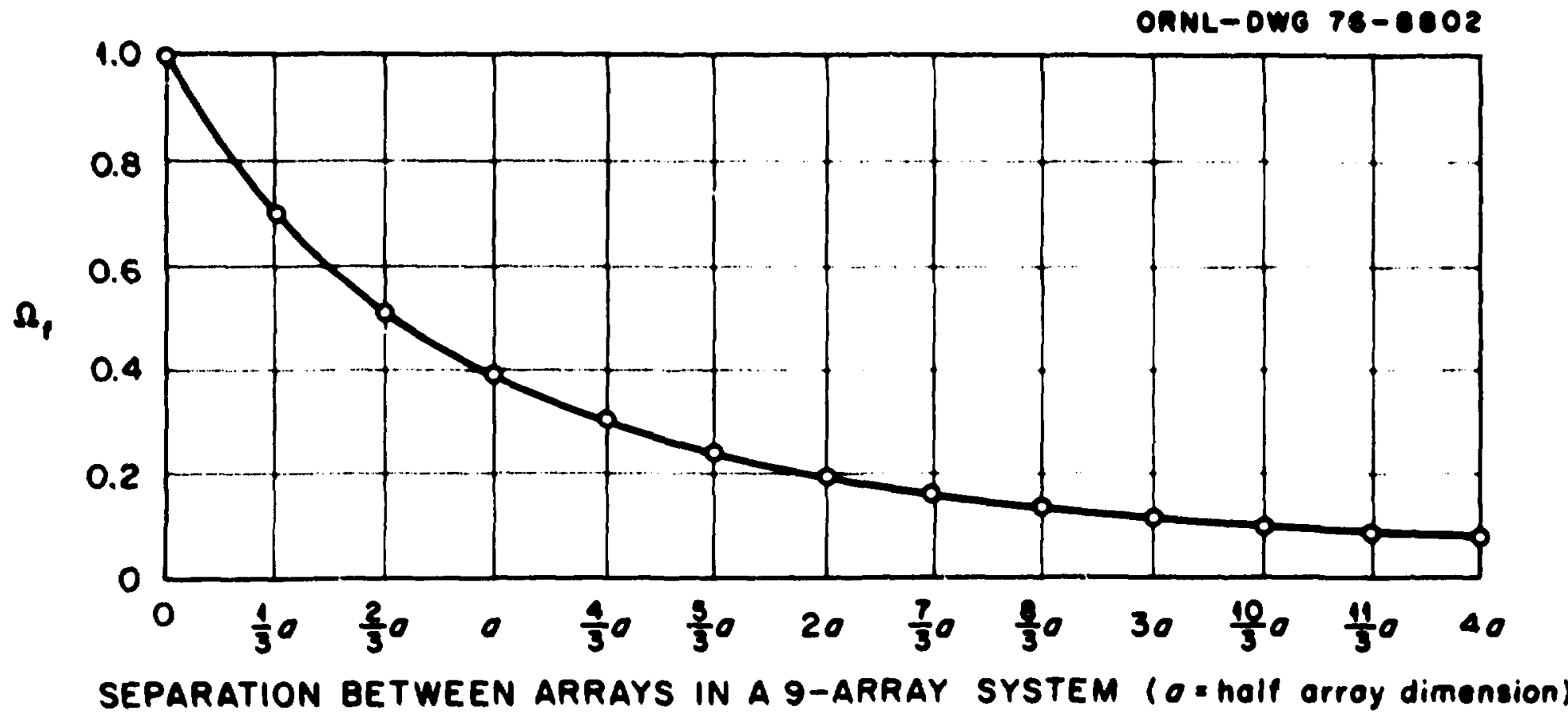

Figure 9. $\Omega_{f}$ vo. Array Separation in Nine-Cublc-Array Syatemu 
ACKNOWLEDGIENTS

The author acknowledges with gratitude the many suggestions and helpful guidance of Mr. J. T. Thomas throughout this work. The assistance of Dr. J. R. Knight in solid angle calculations is sincerely apprectaced. 


\section{REFERDNCES}

1. K. F. Henry, J. R. Knight, and C. E. Newlon, "General Application of a Theory of Neutron Interaction," K-1309 (Nov. 15, 1956).

2. J. A. Pond, "Criticai Geometries for Bare Cylinders," Cat-189 (July, 1956).

3. L. M. Petrie and N. F. Cross, "Keno iV - An Improved Honte Carlo Criticalicy Progran," ORNL-4938 (Novenber, 1975).

4. J. A. Pond, "Right Circular Cylinder, Solfd Angle Calculations," Goodyear Atomic Corp., GAT-Dif-45S (June 5, 1956).

5. D. H. Burton, "Average Solid Angles for Spheres," letter to H. R. Henry, ORGDP, KDA-794 (April 21, 1961).

6. D. H. Burton, "Average Solid Angle," letter tc H. F. Henry, ORGDP (April 30, 1956).

7. Nuclear Safety Guide, Subcomittee 8 of the ASA Sectional Comitrie N6, Project 8 of the ANS Standards Comitcee, USAEC Report, TID-70.6, Rev. 1, p. 35 (1961).

8. L. H. Gilley, D. F. Cronin, J. K. Fox, and J. T. Thomas, "Critical Arrays of Neutron-Interacting Units," Neutron Physics Division Annual Progress Report, ORNL-3193, p. 159 (Oct. 31, 1961).

9. Z. T. Thomas, "Generic Array Criticality - An Analytic Representation of Reflected Arrays of Fissile Units," in Proc. of a short course held at the D. H. Lawrence Ranch near Taos, New Mexico, May 7-11, 1973, USAEC Report, TID-26286, P. 66-83 (1974).

10. J. T. Thomas, "A Criticality Indicator Systen for Storage of Fissile Materials," UCCND/CSE/INF-48 (July, 1975). 